\title{
Design, synthesis, hydrolysis kinetics and phamacodynamic profiles of histidine and alanine conjugates of aceclofenac
}

ARUN RASHEED*

C. K. ASHOK KUMAR

Department of Pharmaceutical Chemistry Sree Vidyanikethan College of Pharmacy Sree Sainath Nagar, Tirupati, Andhra

Pradesh-517102, India

\begin{abstract}
The gastrointestinal toxicity associated with aceclofenac can be reduced by condensing its carboxylic acid group with methyl esters of amino acids like histidine and alanine to give amide linkage by the Schotten-Baumann method. Physicochemical characterization of the conjugates was carried out by various analytical and spectral methods. The synthesized conjugates were also subjected to in vitro hydrolysis in simulated gastric fluid (SGF) at $\mathrm{pH}$ 1.2, simulated intestinal fluid (SIF) at pH 7.4 and SIF+ 80 $\%$ human plasma at $\mathrm{pH}$ 7.4. The release of free aceclofenac from histidine and alanine conjugated aceclofenac showed negligible hydrolysis in SGF compared to SIF. This indicated that the conjugates do not break in stomach, but release aceclofenac in SIF. Both synthesized conjugates showed excellent pharmacological response and encouraging hydrolysis rate in SIF and SIF $+80 \%$ human plasma. Marked reduction of the ulcer index and comparable increase in analgesic and anti-inflammatory activities were obtained in both cases compared to aceclofenac alone. These findings suggest that the conjugates are better in action compared to the parent drug and have fewer gastrointestinal side-effects.
\end{abstract}

Keywords: NSAID, aceclofenac, amino acid conjugate, mutual prodrugs, pharmacokinetics, ulcerogenicity

Aceclofenac (AC), a newer derivative of diclofenac, is one of the emerging NSAIDs for the treatment of arthritis. Successful treatment of arthritis depends on maintenance of the effective drug concentration level in the body for which a constant and uniform supply of drug is desired. However, the problems of side effects after long-term administration of these drugs, such as irritation and ulceration of the GI mucosa, have arisen in clinical trials $(1,2)$. These gastroenteropathies are generally believed to result from the direct contact effect, which can be attributed to the combination of local irritation produced by a free carboxylic group in the molecular structure and by local blockage of prostaglandin biosynthesis in the GI tract. Therefore, the development of new NSAIDs

* Correspondence; e-mail: arunrasheed@rediffmail.com 
without these side-effects has been long awaited. The use of conjugates to provisionally hide the acidic group of NSAIDs was reported providing better lipophilicity, reduced gastric irritancy than the parent drug, improved therapeutic index through prevention of GI irritation and bleeding, improved anti-inflammatory activity, reduced GI erosive properties and synergistic analgesic effect $(3,4)$.

The NSAIDs can be conjugated with amino acids as they possess site specificity and marked healing effect on gastric toxicity. A drug with a free carboxylic acid group can be converted into the corresponding ester or amides of amino acid, to alter the physical properties of the parent drug with the help of enzyme such as amidase, azo reductase and hydrolase, serving as the in vivo reconversion site. Many amino acids also have marked anti inflammatory activity and by using different types of amino acids, viz., non polar, polar, acidic and basic, the drug molecule can be made more or less polar in given solvent.

Literature reveals that many efforts have been made to synthesize conjugates of ketoprofen, diclofenac, flubiprofen, naproxen, ibuprofen, etc., via masking the carboxylic acid group by forming ethyl ester, methyl ester, and glycolamide ester conjugates using various amino acids (5-7). However, no attempts have been made so far to develop amide conjugates of aceclofenac using amino acids, which is the basis of the present study. This paper aims to synthesize amide conjugates of AC with methyl esters of histidine and alanine and to study their various physicochemical properties, hydrolysis kinetics and pharmacological activities.

\section{EXPERIMENTAL}

\section{Materials}

Amino acids L-histidine and L-alanine were obtained from M/s Hi-Media Ltd., India, and aceclofenac was obtained as a gift sample from Alkem Laboratories, India. Other reagents and solvents were of analytical grade. The reactions were monitored by TLC on pre-coated silica $G$ plates using iodine vapour as detecting agent. The melting points were recorded using a melting point determination apparatus from Sigma Instrument, India, and are uncorrected. The elemental analysis was performed using a Carlo-Erba Model 1108 Analyzer (Italy). ${ }^{1} \mathrm{H}$ NMR and ${ }^{13} \mathrm{C}$ NMR spectra were recorded in DMSO on an NMR spectrophotometer (Bruker DRX 300, USA). Chemical shifts are expressed as $\delta$ (ppm) values. IR spectra were recorded using an IR spectrophotometer (Shimadzu 8201 $\mathrm{PC}$, Japan) in $\mathrm{KBr}$ phase and mass spectra were recorded on a mass spectrophotometer (Jeol SX-102 (FAB) (Japan). Hydrolysis data and the drug content were determined using an Elico UV spectrophotometer (India).

\section{Synthesis of histidine and alanine conjugates of aceclofenac}

Aceclofenac is 2-[2-[2-[(2,6-dichlorophenyl)amino]phenyl]acetyl]oxyacetic acid and the synthesis of conjugates was carried out by the Schotten Baumann method (8).

Synthesis of aceclofenac acid chloride (1). - Aceclofenac was dissolved in a minimum amount of chloroform $\left(0.05 \mathrm{~mol} \mathrm{~L}^{-1}\right)$ and freshly distilled thionyl chloride $\left(0.05 \mathrm{~mol} \mathrm{~L}^{-1}\right)$ 
A. Rasheed and C. K. Ashok Kumar: Design, synthesis, hydrolysis kinetics and phamacodynamic profiles of histidine and alanine conjugates of aceclofenac, Acta Pharm. 60 (2010) 99-109.

was added slowly. The mixture was refluxed for $15 \mathrm{~h}$ at $60-70{ }^{\circ} \mathrm{C}$ under continuous stirring on a magnetic stirrer. The viscous liquid was immediately poured on a Petri dish and it was vacuum dried to give yellow coloured crude aceclofenac acid chloride (1).

Synthesis of methyl ester hydrochlorides of L-histidine and L-alanine $(2 \boldsymbol{a}, \boldsymbol{b})$. - Freshly distilled thionyl chloride $\left(0.05 \mathrm{~mol} \mathrm{~L}^{-1}\right)$ was slowly added to methanol $(100 \mathrm{~mL})$ with cooling and histidine (2) $\left(0.1 \mathrm{~mol} \mathrm{~L}^{-1}\right)$ was added. The mixture was refluxed for $6-8 \mathrm{~h}$ at $60-70{ }^{\circ} \mathrm{C}$ under continuous stirring on a magnetic stirrer. Excess thionyl chloride and solvent were removed under reduced pressure giving crude histidine methyl ester hydrochloride. It was treated with a $20 \mathrm{~mL}$ portion of cold ether at $0{ }^{\circ} \mathrm{C}$. The resulting solid product was collected and dried under vacuum. It was re-crystallized from hot methanol by slow addition of $15-20 \mathrm{~mL}$ ether followed by cooling at $0{ }^{\circ} \mathrm{C}$. The crystals were collected on the following day and washed twice with an ether/methanol mixture $5: 1$ ratio) followed by pure ether and dried under vacuum to give pure histidine methyl ester hydrochloride (2a). The same procedure was followed to synthesize alanine methyl ester hydrochloride (2b) (9).

Synthesis of aceclofenac conjugates with methyl esters of L-histidine and L-alanine $(3 \boldsymbol{a}, \boldsymbol{b})$. - Ice-cold, aqueous sodium hydroxide solution (5\%) was placed into a $250 \mathrm{~mL}$ beaker and methyl ester of L-histidine or L-alanine hydrochloride $\left(0.05 \mathrm{~mol} \mathrm{~L}^{-1}\right)$ was added. The reaction mixture was mechanically stirred for $30 \mathrm{~min}$ at room temperature, then the beaker was transferred to an ice bath kept on a mechanical stirrer, maintaining the temperature at $10{ }^{\circ} \mathrm{C}$. Aceclofenac acid chloride $\left(0.01 \mathrm{~mol} \mathrm{~L}^{-1}\right)$ was added in small portions under continuous stirring for $7-8 \mathrm{~h}$. The solid that separated out was filtered off. The crude conjugate was re-crystallized from methanol. Schematic representations of the synthesis of histidine conjugated aceclofenac (3a) and alanine conjugated aceclofenac (3b) are given in Scheme 1.

\section{Characterization of synthesized conjugates}

The structure of synthesized compounds was established by elemental analysis, ${ }^{1} \mathrm{H}$ NMR, ${ }^{13}$ C NMR, and FTIR spectral methods (Tables I and II). The purity was determined by TLC using silica gel and the physicochemical parameters were determined.

Protein binding studies (10). - A solution of the synthesized conjugate (10 mg mL-1$)$ was prepared in phosphate buffered saline (PBS, pH 7.4). $100 \mathrm{~mL}$ of this solution was placed in a beaker. The cellophane membrane (molecular mass cut off in the range of 10000-12000 Da obtained from Hi-Media, India) was first washed with distilled water and then with buffer solution ( $\mathrm{pH}$ 7.4). It was tied at the opening end of a dialysis tube; the dialysis tube containing ( $6 \%$ ) egg albumin was dipped into the drug solution and covered. The whole assembly was placed on a magnetic stirrer and set at low revolutions per minute. The temperature was maintained at $37 \pm 0.5^{\circ} \mathrm{C}$. After each $1 \mathrm{~h}, 1 \mathrm{~mL}$ of the PBS containing drug solution was replaced with fresh $1 \mathrm{~mL}$ of PBS. The withdrawn sample was further diluted with $1 \mathrm{~mL}$ phosphate buffer and the concentration of the conjugate was estimated using a spectrophotometer at $230 \mathrm{~nm}$.

Hydrolysis rate determination of synthesized conjugates (11). - In vitro hydrolysis studies of synthesized conjugates were carried out in simulated gastric fluid (SGF) at $\mathrm{pH} 1.2$, 
A. Rasheed and C. K. Ashok Kumar: Design, synthesis, hydrolysis kinetics and phamacodynamic profiles of histidine and alanine conjugates of aceclofenac, Acta Pharm. 60 (2010) 99-109.

simulated intestinal fluid (SIF) at $\mathrm{pH} 7.4$ and SIF $+80 \%$ human plasma at $\mathrm{pH} 7.4$. A solution of $10 \mathrm{mg}$ of conjugate was prepared in $90 \mathrm{~mL}$ of SIF (pH 7.4) or SGF (pH 1.2). An aliquot of $15 \mathrm{~mL}$ of this solution was withdrawn repeatedly and kept in test tubes maintained at $37 \pm 0.5^{\circ} \mathrm{C}$. At a definite time interval $(0.5 \mathrm{~h}, 1-8 \mathrm{~h})$, an aliquot was withdrawn from different test tubes and was transferred to micro centrifuge tubes, followed by addition of methanol to make up the volume. The tubes were placed in a freezing mixture in order to arrest further hydrolysis, followed by vortexing at high speed for $5 \mathrm{~min}$. After vortexing, the tubes were centrifuged at high speed ( $3000 \mathrm{rpm}$ ) for $5 \mathrm{~min} .5 \mathrm{~mL}$ of clear supernatant obtained from each tube was measured by a spectrophotometer for the amount of free aceclofenac released after the hydrolysis of prodrugs in SGF, SIF and SIF $+80 \%$ human plasma at $230 \mathrm{~nm}$. The kinetics of hydrolysis was monitored by the increase of free drug concentration with time and the order of the reaction and half-life $\left(t_{1 / 2}\right)$ were also calculated. The rate of hydrolysis was calculated using the equation:

$$
k_{\mathrm{H}}=(2.303 / t) \log (a / a-x)
$$

where $k_{\mathrm{H}}$ represents the hydrolysis constant, $t$ is the time in min, $a$ is the initial conjugate concentration, $x$ is the amount of conjugate hydrolyzed and $(a-x)$ is the amount of the remaining conjugate.

\section{Pharmacological evaluations}

Aceclofenac as well as the synthesized conjugates were evaluated for analgesic, anti-inflammatory and ulcerogenic activity. Histopathology and a comparative study were also performed. Test compounds and standard drugs were administered in the form of a suspension ( $1 \%$ carboxymethylcellulose as vehicle) by the oral route of administration for analgesic and anti-inflammatory studies, but intraperitoneally as suspension in $2 \%$ $(m / V)$ acacia for ulcerogenicity studies. Wistar albino rats (100-200 g) of four groups, including a control and a standard group, with six animals each were selected. The selected animals were housed in acrylic cages under standard environmental conditions at $25 \pm 2{ }^{\circ} \mathrm{C}$, relative humidity of $45-55 \%$, in a well ventilated room maintained at a $12: 12 \mathrm{~h}$ light:dark cycle, and were fed a standard rodent diet and water ad libitum. All the animals were acclimatized for a week before experiment. All animal experiments were carried out according to the guidelines of the Committee for the Purpose of Control of Experiments on Animals and Approval of the Institutional Animal Ethics Committee, Sree Vidyanikethan College of Pharmacy, Tirupati, India was obtained.

Anti-inflammatory activity. - The anti-inflammatory activity was determined by the hind paw oedema method (12) using carrageenean as phlogistic agent. Wistar albino rat were divided into four groups, of six rats each, including a control and a standard group. The initial right hind paw volume was measured using a plethysmometer without conjugate administration. The conjugate, $10 \mathrm{mg} \mathrm{kg}^{-1}$ body mass, was administered orally in a $1 \%$ suspension of sodium carboxymethylcellulose (containing $0.1 \%, m / V$, of conjugate). After $30 \mathrm{~min}$ of conjugate administration, the carrageenean $(0.1 \mathrm{~mL}, 1 \%, m / V$ solution in normal saline was injected into the planta surface of the right hind paw of each animal. The volume of the right hind paw of the albino rat was measured after 2, 4 and $6 \mathrm{~h}$. 
Analgesic activity. - The analgesic activity was determined by the thermal stimulus using the tail flick method (13). An analgesiometer was used to determine the pain threshold of albino rats. Cold water was circulated through the water jackets of the instrument to avoid heating of the area around the hot wire. The rat (100-200 g) was placed in a holder through which its tail was protruded out. The reaction time was recorded at 30 $\min , 1,2$ and $3 \mathrm{~h}$ after the treatment and the cut-off time was $9 \mathrm{~s}$. The normal reaction time, i.e., the time taken to flick the tail was noted. Animals showing delayed response were rejected. The conjugate (dose of each conjugate was calculated to be equivalent to $10 \mathrm{mg} \mathrm{kg}^{-1}$ body mass) was administered orally in a $1 \%$ suspension of sodium carboxymethylcellulose.

Ulcerogenicity index. - Gastrointestinal toxicity of the synthesized conjugates was measured and compared with the parent drug by measuring the ulcer index (14). The control group was administered only a $2 \%(\mathrm{~m} / \mathrm{V})$ acacia suspension intraperitoneally. Measured volume of the suspension containing a dose equivalent to $10 \mathrm{mg} \mathrm{kg}^{-1}$ of body mass of AC was administered orally to the test group daily for 5 days. The rats (130-150 g) were fasted after administration of the last dose, then they were sacrificed by decapitation and the stomach was removed, opened and washed with distilled water. Lesions on the gastric mucosa were counted by visual examination using a binocular magnifier. Ulcers larger than $0.5 \mathrm{~mm}$ were recorded. The mean ulcer index (UI) was calculated according to severity of gastric mucosal lesions graded as: grade $1-$ less than 1-mm erosions, grade $2-1-2-m m$ erosions, grade $3-$ more than 2 -mm erosions.

The UI was calculated as: UI $=[1 \times($ number of lesions of grade 1$)+2 \times($ number of lesions of grade 2$)+3 \times($ number of lesions of grade 3$)] / 10$.

Histopathological studies. - Histopathological studies of rat stomach were carried out using haemotoxylin and eosin stain (15) at the Pathology Department, Sri Venkateswara Veterinary University, Tirupati, India. Stomach tissues were removed from the rats and fixed in $10 \%$ normal saline for at least $48 \mathrm{~h}$. These were then processed routinely and the tissues were embedded in paraffin wax. Histological sections were cut at 5-6 $\mu \mathrm{m}$ and stained with standard haematoxylin and eosin. The lesions observed were assessed for

Table I. Physicochemical properties of synthesized conjugates of aceclofenac

\begin{tabular}{|c|c|c|c|c|c|c|c|c|}
\hline \multirow{2}{*}{$\begin{array}{c}\text { Drug } \\
\text { conjugate }\end{array}$} & \multirow{2}{*}{$\begin{array}{l}\text { Molecular } \\
\text { formula }\end{array}$} & \multirow{2}{*}{$M_{\mathrm{r}}$} & \multirow{2}{*}{$\begin{array}{c}\text { Melting } \\
\text { point }\left({ }^{\circ} \mathrm{C}\right)^{\mathrm{a}}\end{array}$} & \multirow{2}{*}{$\begin{array}{c}\text { Yield } \\
(\%)\end{array}$} & \multirow{2}{*}{$\begin{array}{c}\text { Protein } \\
\text { binding (\%) }\end{array}$} & \multicolumn{3}{|c|}{ Elemental analysis } \\
\hline & & & & & & \multicolumn{2}{|c|}{ Calcd. (\%) } & \multirow{2}{*}{$\begin{array}{c}\text { Found }(\%) \\
55.11\end{array}$} \\
\hline \multirow{4}{*}{$3 a$} & \multirow{4}{*}{$\mathrm{C}_{23} \mathrm{H}_{22} \mathrm{Cl}_{2} \mathrm{~N}_{4} \mathrm{O}_{5}$} & \multirow{4}{*}{504.65} & \multirow{3}{*}{ 191-192 } & \multirow{4}{*}{65} & \multirow{3}{*}{64.0} & $\mathrm{C}$ & 54.96 & \\
\hline & & & & & & $\mathrm{H}$ & 4.37 & 4.53 \\
\hline & & & & & & $\mathrm{N}$ & 13.88 & 13.98 \\
\hline & & & \multirow{3}{*}{ 195-196 } & & \multirow{3}{*}{71.65} & C & 53.79 & 53.46 \\
\hline \multirow[t]{2}{*}{$3 b$} & \multirow[t]{2}{*}{$\mathrm{C}_{20} \mathrm{H}_{20} \mathrm{Cl}_{2} \mathrm{~N}_{2} \mathrm{O}_{5}$} & \multirow[t]{2}{*}{348.23} & & \multirow[t]{2}{*}{97} & & $\mathrm{H}$ & 4.59 & 4.45 \\
\hline & & & & & & $\mathrm{N}$ & 15.98 & 15.67 \\
\hline
\end{tabular}

a Uncorrected 
A. Rasheed and C. K. Ashok Kumar: Design, synthesis, hydrolysis kinetics and phamacodynamic profiles of histidine and alanine conjugates of aceclofenac, Acta Pharm. 60 (2010) 99-109.
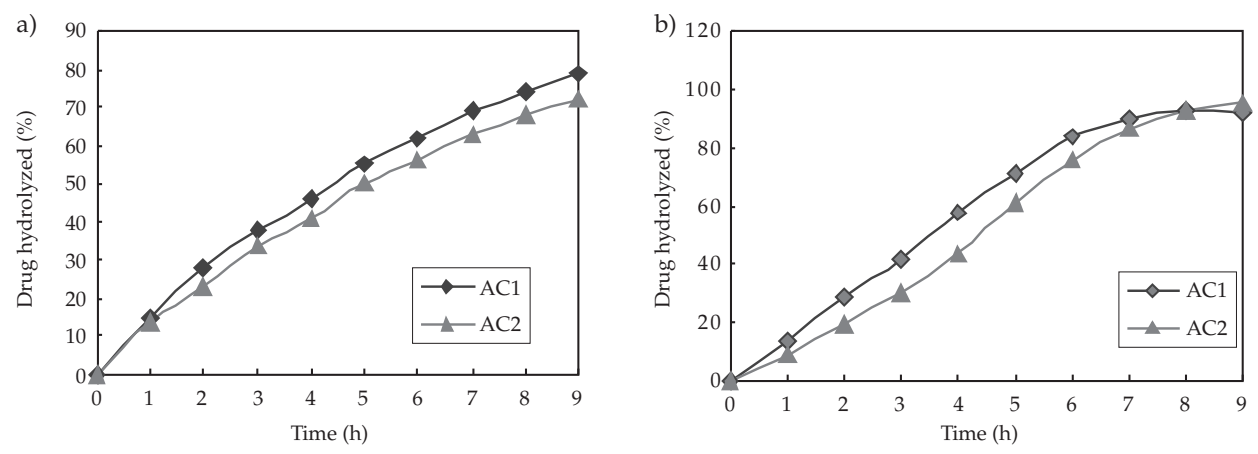

Fig. 1. Comparative pattern of hydrolysis of: a) $\mathbf{3} \mathbf{a}$ and $\mathbf{3} \mathbf{b}$ in SIF, b) $\mathbf{3} \mathbf{a}$ and $\mathbf{3 b}$ in SIF $+80 \%$ plasma.

subsequent mucosal atrophy, the presence of inflammatory cells in the wall, oesinophils, lymphocytes and plasma cells. Photomicrographs of representative lesions were taken at various magnifications on a Zeiss optical microscope, Stemi 2000-C (Germany), with a resolution of $10 \times 45 \mathrm{X}$, with a trinocular camera attached.

\section{Statistical analysis}

Statistical analysis of the pharmacological activity data of the synthesized prodrugs on animals was evaluated using a one-way analysis of variance (ANOVA). Student's $t$-test was applied to express the significance. Data are expressed as mean \pm SD (standard deviation).

\section{RESULTS AND DISCUSSION}

The conjugates 3a $\{N$ - $[\beta$-immidazole-3-yl- $\alpha$-(methylpropionate) $] 2[((2,6$-dichloro phenyl)aminophenylacetoxyacetamide) $]\}$ and $3 \mathbf{b}\{N$-(methylpropionate) $2[((2,6$-dichlorophenyl)aminophenylacetoxyacetamide)]\} were prepared from methyl esters of alanine and histidine and acid chlorides of aceclofenac (Scheme 1).

The conjugates $\mathbf{3 a}$ and $\mathbf{3} \mathbf{b}$ were subjected to solubility, physicochemical characterization, protein binding and hydrolytic studies. The solubility studies showed that $\mathbf{3 a}$ and $3 \mathbf{b}$ were highly soluble in methanol, slightly soluble in $\mathrm{NaOH}$ and insoluble in 0.1 mol L ${ }^{-1} \mathrm{HCl}$. They showed moderate to high solubility in chloroform, ethanol and acetone. Higher solubility of the standard drug AC (1) is mainly due to the presence of free carboxylic acid, which forms sodium salt and makes the compound ionic. But, the conjugates $\mathbf{3 a}$ and $\mathbf{3 b}$, which show moderate to high solubility in organic solvents, indicate lipophilic behaviour. Physicochemical properties of the synthesized conjugates are shown in Table I. Results of the elemental analysis of synthesized conjugates were in all cases within $\pm 0.4 \%$ of theoretical values and confirmed the desired structure. The $\mathrm{IR},{ }^{1} \mathrm{H}$ NMR, ${ }^{13} \mathrm{C}$ NMR and mass spectral data of synthesized conjugates are shown in Table II. 
<smiles>[R]Oc1c[nH]c(CCC)c1</smiles>

Scheme 1

The half-life $\left(t_{1 / 2}\right)$ of conjugate $3 \mathbf{a}$ in SIF was found as $4.5 \mathrm{~h}$ and that of $\mathbf{3 b}$ as $4.4 \mathrm{~h}$. The comparative pattern of hydrolysis of these conjugates in SIF ( $\mathrm{pH} 7.4$ ) is shown in Fig. 1a. The amount of AC regenerated by hydrolysis of $\mathbf{3 a}$ and $\mathbf{3 b}$ was found to be 79 and $72 \%$, respectively. The comparative pattern of hydrolysis of conjugates in SIF $+80 \%$ human plasma is shown in Fig. 1b. The amount of AC regenerated by hydrolysis of 3a and $3 \mathbf{b}$ was found to be 92 and $95 \%$, respectively. Satisfactory hydrolysis of the conjugates was observed in SIF and very encouraging hydrolysis in SIF $+80 \%$ human plasma. The latter is due to the presence of amidase in plasma. Thus, the hydrolytic kinetics study revealed that both $\mathbf{3 a}$ and $\mathbf{3 b}$ followed first-order kinetics (Fig. 2). The percentage protein binding of conjugates $3 \mathbf{a}$ and $3 \mathbf{b}$ was found to be 64 and $72 \%$ respectively. The conjugates showed comparatively low protein binding compared to the standard drug, whose value is $75 \%$. This increases the availability of conjugates for hydrolysis in plasma and the required dose will be lower.

Table II. Spectral data of $3 a$ and $3 b$

\begin{tabular}{|c|c|c|c|c|}
\hline $\begin{array}{c}\text { Drug } \\
\text { conjugate }\end{array}$ & $\begin{array}{l}\text { Mass } \\
(m / z)\end{array}$ & $\mathrm{IR}\left(\mathrm{KBr}, \mathrm{cm}^{-1}\right)$ & $\begin{array}{c}{ }^{1} \mathrm{H} \mathrm{NMR}(\delta, \mathrm{ppm}) \\
(\mathrm{DMSO})\end{array}$ & $\begin{array}{c}{ }^{13} \mathrm{C} \mathrm{NMR}(\delta, \mathrm{ppm}) \\
\text { (DMSO) }\end{array}$ \\
\hline $3 a$ & $504(\mathrm{M}+)$ & $\begin{array}{l}3395 \text { (NH), } 2860 \\
\text { (CH str.), } 1765 \\
(\mathrm{C}=\mathrm{O}), 1580 \text { (amide), } \\
1270 \text { (C-O } \\
\text { ester str.) }\end{array}$ & $\begin{array}{l}9.77(1 \mathrm{H}, \mathrm{NH}), 8.32 \\
(4 \mathrm{H}, \mathrm{ArH}), 7.28(1 \mathrm{H}, \\
\mathrm{NH}), 4.97(2 \mathrm{H}, \\
\mathrm{CH}=\mathrm{CH}), 3.72(2 \mathrm{H}, \\
\left.\mathrm{OCH}_{3}\right), 3.68(2 \mathrm{H}, \\
\left.\mathrm{CH}_{2} \mathrm{CH}_{3}\right), 2.35(1 \mathrm{H}, \\
\mathrm{CH} \text { in ring) }\end{array}$ & $\begin{array}{l}35.2,36.2,47.8,51.9, \\
63.2,63.2,118.6,120.0, \\
125.2,127.0,127.1 \\
127.1,127.3,128.4 \\
128.4,128.9,128.9, \\
135.3,139.6,139.6 \\
166.4,169.2,172.1\end{array}$ \\
\hline $3 b$ & $348(\mathrm{M}+)$ & $\begin{array}{l}3365(\mathrm{NH}), 1780 \\
(\mathrm{C}=\mathrm{O}), 1640 \text { (amide), } \\
1560 \text { (amide II), } \\
1490(\mathrm{C}-\mathrm{H}), \\
1255 \text { (C-O ester) }\end{array}$ & $\begin{array}{l}8.32(4 \mathrm{H}, \mathrm{ArH}), 8.28 \\
(1 \mathrm{H}, \mathrm{NH}), 6.69-6.98 \\
(2 \mathrm{H}, \mathrm{CH}=\mathrm{CH}), 4.97 \\
(2 \mathrm{H}, \mathrm{CH}=\mathrm{CH}), 3.68 \\
\left(2 \mathrm{H}, \mathrm{OCH}_{3}\right), 4.35(2 \mathrm{H}, \\
\left.\mathrm{CH}_{2} \mathrm{CH}_{3}\right), 3.72(2 \mathrm{H}, \\
\left.\mathrm{COOCH}_{2}\right), 1.48(1 \mathrm{H}, \\
\mathrm{CH} \text { in ring })\end{array}$ & $\begin{array}{l}17.3,35.2,47.8,51.9, \\
63.2,118.6,120.0,125.2, \\
127.0,127.4,127.6, \\
128.4,128.9,135.3, \\
139.6,139.6,128.9, \\
168.6,171.2,172.9\end{array}$ \\
\hline
\end{tabular}


A. Rasheed and C. K. Ashok Kumar: Design, synthesis, hydrolysis kinetics and phamacodynamic profiles of histidine and alanine conjugates of aceclofenac, Acta Pharm. 60 (2010) 99-109.

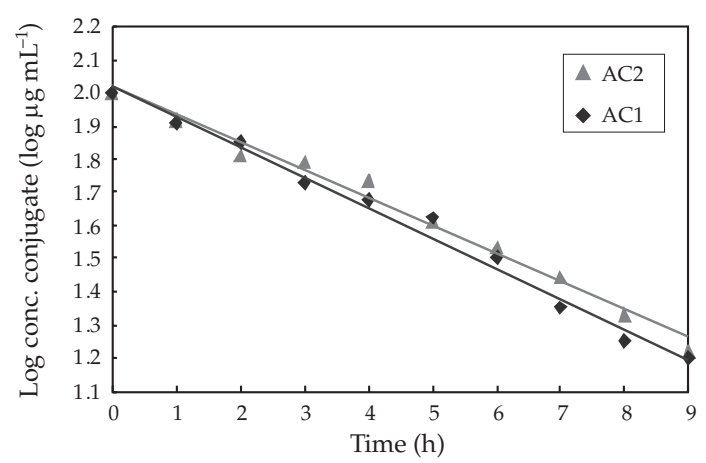

Fig. 2. First-order hydrolysis plot of $\mathbf{3 a}$ and $\mathbf{3 b}$ in SIF $+80 \%$ plasma.

Pharmacological investigations of the synthesized conjugates were carried out for anti-inflammatory, analgesic and ulcerogenic activities (Table III). The dose of $\mathbf{3 a}$ and $\mathbf{3 b}$ administered was equivalent to $10 \mathrm{mg} \mathrm{kg}^{-1}$ body mass of the parent drug AC.

The anti-inflammatory activity obtained after 2 and $6 \mathrm{~h}$ of administration of the standard drug AC were found to be 61 and $45 \%$ whereas for conjugates $\mathbf{3 a}$ and $\mathbf{3 b}$ they were 67 and $75 \%$ after $6 \mathrm{~h}$ (Table III). The anti-inflammatory activity of free AC decreased with time while that of its conjugates increased with time due to their higher bioavailability compared to the parent drug. Maximum anti-inflammatory activity of conjugates $3 \mathbf{a}$ and $3 \mathbf{b}$ was observed after $6 \mathrm{~h}$ and remained practically constant up to $8 \mathrm{~h}$. The statistical significance was tested by one way ANOVA followed by Dunnett's test. The data showed significantly higher anti-inflammatory activity of $\mathbf{3 a}$ and $\mathbf{3 b}$ compared to AC (standard drug) after 4 and $6 \mathrm{~h}$.

The analgesic activity of synthesized conjugates $3 \mathbf{a}$ and $3 \mathrm{~b}$ after $1 \mathrm{~h}$ of administration was found to be 28 and $31 \%$, respectively while that of AC was $60 \%$ (Table III). After $4 \mathrm{~h}$ of drug administration, the analgesic activity of the parent drug was reduced to $48 \%$, while that of $3 \mathbf{a}$ and $3 \mathbf{b}$ increased to 52 and $45 \%$, respectively. This revealed that the analgesic activity of AC decreased with time, but the synthesized products showed sustained analgesic activity. This may be due to higher bioavailability of the synthesized conjugates.

Table III. Comparative pharmacological data of AC, $3 a$ and $3 b$

\begin{tabular}{|c|c|c|c|c|c|c|c|c|}
\hline \multirow{2}{*}{$\begin{array}{l}\text { Drug } \\
\text { conjugate }\end{array}$} & \multicolumn{3}{|c|}{$\begin{array}{l}\text { Anti-inflammatory activity } \\
(\%)^{\mathrm{b}}\end{array}$} & \multicolumn{4}{|c|}{$\begin{array}{l}\text { Analgesic activity } \\
(\%)^{\mathrm{b}}\end{array}$} & \multirow{2}{*}{$\begin{array}{l}\text { Ulcer } \\
\text { index }^{b}\end{array}$} \\
\hline & $2 \mathrm{~h}$ & $4 \mathrm{~h}$ & $6 \mathrm{~h}$ & $1 \mathrm{~h}$ & $2 \mathrm{~h}$ & $3 \mathrm{~h}$ & $4 \mathrm{~h}$ & \\
\hline $\mathrm{AC}$ & $62 \pm 2$ & $50 \pm 1$ & $45 \pm 1$ & $60 \pm 2$ & $62 \pm 1$ & $52 \pm 1$ & $48 \pm 2$ & $28 \pm 2$ \\
\hline $3 a$ & $58 \pm 1^{c}$ & $64 \pm 2^{c}$ & $67 \pm 1^{c}$ & $28 \pm 1^{c}$ & $50 \pm 1^{c}$ & $51 \pm 1^{\mathrm{c}}$ & $52 \pm 1^{c}$ & $6 \pm 1^{c}$ \\
\hline $3 b$ & $64 \pm 1^{c}$ & $68 \pm 1^{c}$ & $75 \pm 2^{c}$ & $31 \pm 2^{\mathrm{c}}$ & $51 \pm 2^{c}$ & $46 \pm 1^{\mathrm{c}}$ & $45 \pm 1^{c}$ & $5 \pm 1^{\mathrm{c}}$ \\
\hline
\end{tabular}

Control animals were administered orally $1 \%$ carboxymethylcellulose.

b Mean \pm SD, $n=6$.

c Significantly different $v$ s. AC, $p<0.05$. 
The ulcer index of the synthesized conjugates was recorded to observe the extent of gastrointestinal side effects (Table III). The mean ulcer index of the standard drug AC was found to be 28 and for the conjugates $3 \mathbf{a}$ and $3 \mathbf{b} 6$ and 5 , respectively. The minimized side effect obtained in the conjugates might be due to inhibition of the direct contact of the carboxylic acid group of the drug to the gastric mucosa which is mainly responsible for the damage.

The histopathological findings are summarized as follows. Gastric tissues were investigated microscopically and the tissue samples of control group rats showed normal histological findings (Fig. 3). Microscopic investigation of the AC group revealed a focal erosive area in gastric mucosa and a zone (clear zone) in the basal regions of the gastric glands stained pale. This zone was parallel to the surface of the stomach lumen. In this zone, the structures of the gland were destroyed. They had disintegrated from the basal lamina and fallen into the lumen. The nuclei of these cells became smaller and dense, and their cytoplasms were stained as dark eosinophilic bodies. Small hemorrhagic areas and patches of inflammatory cell infiltrations were present in the lumen of the glands and lamina propria. Normal histological findings were displayed for both $3 \mathbf{a}$ and $\mathbf{3 b}$ revealing that the conjugates are not producing any ulceration in the gastric region.

a)

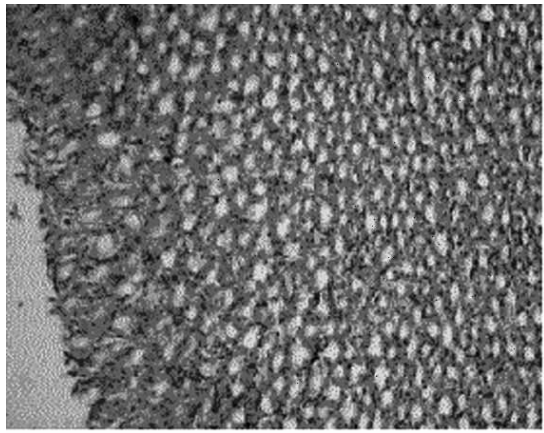

c)

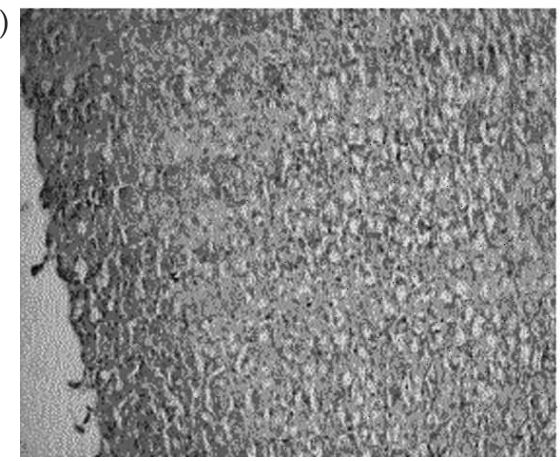

b)

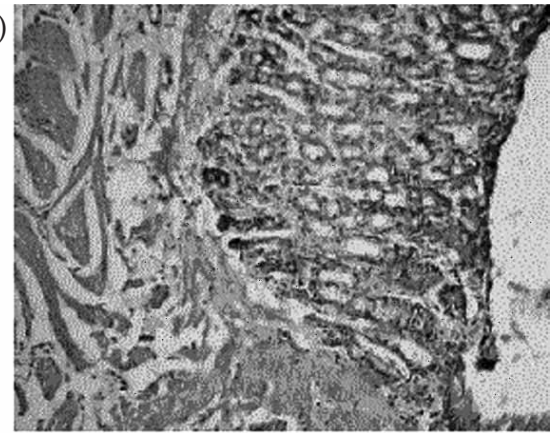

d)

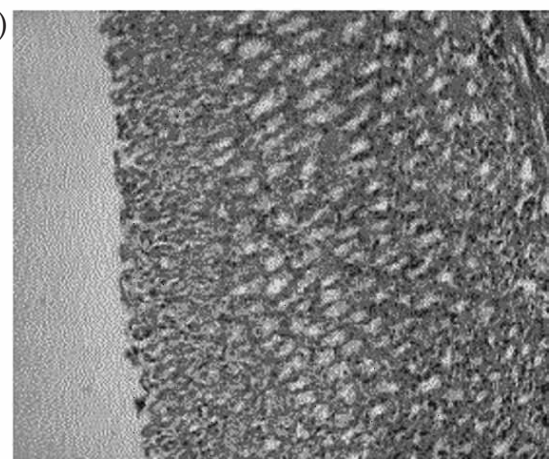

Fig. 3. Histopathological studies of conjugates: a) healthy control, b) ulcer control showing mucosal injury characterized by AC and massive mucosal infiltration of inflammatory cells, c) treated with $3 \mathbf{a}, \mathrm{d})$ treated with $\mathbf{3 b}$. 


\section{CONCLUSIONS}

Histidine and alanine containing aceclofenac amide conjugates were successfully synthesized and the structure was confirmed based on their spectral analysis. Both 3a and $\mathbf{3 b}$ showed an excellent pharmacological response and encouraging hydrolysis rate in SIF $+80 \%$ of human plasma. Lower protein binding of the conjugates increased its availability for hydrolysis in plasma and thus resulted in a lower dose requirement. Increased anti-inflammatory and analgesic activities as well as reduction of the ulcer index of the conjugates were observed when compared to the parent drug. The histopathological findings revealed that there was limited ulcer formation in the stomach by the conjugates. On the basis of the above observations, it is concluded that these conjugates can be successfully applied to attain the goal of minimized gastro-intestinal toxicity without loss of the desired anti-inflammatory and analgesic activity of the drug.

Acknowledgements. - The authors express their thanks to M/s. Alkem Laboratories, Mumbai, India, for providing a gift sample of aceclofenac. The authors are grateful to Padmashree Dr. M. MohanBabu, Chairman, Sree Vidyanikethan Educational Trust, Tirupati, India, for providing the necessary facilities to carry out this work.

\section{REFERENCES}

1. Analgesics Anti-Inflammatory and Antipyretics, in Martindale: The Complete Drug Reference (Ed. K. Parfitt), 32 ${ }^{\text {nd }}$ ed., Pharmaceutical Press, London 1999, pp. 61-62.

2. A. E. Kay and A. Alldred, Rheumatoid Arthritis and Osteoarthritis, in Clinical Pharmacy and Therapeutics (Eds. R. Walker and C. Edwards), 3rd ed., Churchill Livingstone, London 2003, pp. 791807.

3. A. Mishra, V. Ravichandran, P. K. Jain, V. K. Dixit and R. K. Agrawal, Synthesis, characterization and pharmacological evaluation of amide prodrugs of flubiprofen, J. Braz. Chem. Soc. 19 (2008) 89-100; DOI: 10.1590/S0103-50532008000100014.

4. A. Mishra, V. Ravichandran, P. K. Jain, V. K. Dixit and R. K. Agrawal, Synthesis, characterization and pharmacological evaluation of amide prodrugs of ketorolac, Eur. J. Med. Chem. 43 (2008) 2464-2472; DOI: 10.1016/j.ejmech.2007.09.011.

5. D. Bhosle, S. Bharambe, N. Gairola and S. S. Dhaneshwar, Mutual prodrug concept: fundamentals and applications, Indian J. Pharm. Sci. 68 (2006) 286-294; DOI: 10.4103/0250-474X.26654.

6. A. Rasheed and C. K. A. Kumar, Novel approaches on prodrug based drug design, Pharm. Chem. J. 42 (2008) 677-686; DOI: 10.1007/s11094-009-0213-3.

7. S. D. Roy and E. Manoukian, Permeability of ketorolac acid and its ester analogs (prodrug) through human cadaver skin, J. Pharm. Sci. 83 (1994) 1548-1553; DOI: 10.1002/jps.2600831106.

8. J. R. Idle, P. Millburn and R. T. Williams, Taurine conjugates as metabolites of arylacetic acids in the ferret, Xenobiotica 8 (1978) 253-264; DOI: 10.3109/00498257809056147.

9. N. Gairola, D. Nagpal, S. S. Dhaneshwar, S. R. Dhaneshwar and S. C. Chaturvedi, Synthesis, hydrolysis kinetics and pharmacodynamic profiles of novel prodrugs of flubiprofen, Indian J. Pharm. Sci. 67 (2005) 369-373.

10. A. Rasheed, V. Ravichandran and D. V. Kohli, Ampicillin prodrugs: amide conjugates from amino acids, peptide and ampicillin, Pharmazie 54 (1999) 857-858. 
A. Rasheed and C. K. Ashok Kumar: Design, synthesis, hydrolysis kinetics and phamacodynamic profiles of histidine and alanine conjugates of aceclofenac, Acta Pharm. 60 (2010) 99-109.

11. N. W. Nielsenw and H. Bundgaard, Glycolamide esters as biolabile prodrugs of carboxylic acid agents: synthesis, stability, bioconversion, and physicochemical properties, J. Pharm. Sci. 77 (1988) 285-298; DOI: 10.1002/jps.2600770402.

12. C. A. Winter, E. A. Risely and G. W. Nuss, Carregeenan induced oedema in hind paw of the rat as assay for anti-inflammatory drugs, Exp. Biol. Med. 111 (1962) 544-547.

13. S. K. Kulkarni, Heat and other physiological stress-induced analgesia: catecholamine mediated and naloxone reversible response, Life Sci. 27 (1980) 185-188; DOI: 10.1016/0024-3205(80)90136-8.

14. R. K. Goyal, A. Chakrabarti and A. K. Sanyal, The effect of biological variables on the anti-ulcerogenic effect of vegetable plantain banana, Planta Med. 29 (1985) 85-88; DOI: 10.1055/s-2007$-969412$.

15. M. Yagmurca, M. Ucar, E. Fadillioglu, H. Erdogan and F. Ozturk, The effects of nitric oxide on rat stomach injury induced by acetylsalicylic acid, Turk. J. Med. Sci. 39 (2009) 13-19; DOI: 10.3906/ sag-0712-22.

\section{Dizajniranje, sinteza, kinetika hidrolize i farmakodinamski profili konjugata aceklofenaka $s$ histidinom $i$ alaninom}

ARUN RASHEED i C. K. ASHOK KUMAR

Gastrointestinalna toksičnost aceklofenaka može se umanjiti kondenzacijom karboksilne skupine aceklofenaka s metilnim esterima aminokiselina poput histidina i alanina, pri čemu se stvaraju nove amidne veze po Schotten-Baumannovoj metodi. Fizikokemijska karakterizacija konjugata provedena je različitim analitičkim i spektralnim metodama. Nadalje, praćena je hidroliza sintetiziranih konjugata in vitro u simuliranoj gastričnoj tekućini (SGF) pri pH 1,2, simuliranoj intestinalnoj tekućini (SIF) pri pH 7,4 i simuliranoj intestinalnoj tekućini s $80 \%$ humane plazme pri $\mathrm{pH}$ 7,4. Oslobađanje aceklofenaka iz konjugata s histidinom, odnosno alaninom, bilo je zanemarivo u SGF-u, u odnosu na oslobađanje u SIF-u. To ukazuje da su konjugati stabilni u želucu, dok se u SIF-u iz njih oslobađa aceklofenak. Oba konjugata daju izvrstan farmakološki odgovor i zadovoljavajući stupanj hidrolize u SIF-u i smjesi SIF-a i humane plazme. Oba konjugata pokazala su značajno smanjenu ulcerogenost i pojačano analgetsko i protuupalno djelovanje u odnosu na aceklofenak. Rezultati ukazuju na prednost konjugata u odnosu na samu ljekovitu tvar.

Ključne riječi: aceklofenak, aminokiselinski konjugat, prolijekovi, farmakokinetika, ulcerogenost

Department of Pharmaceutical Chemistry, Sree Vidyanikethan College of Pharmacy, Sree Sainath Nagar Tirupati, Andhra Pradesh-517102, India 